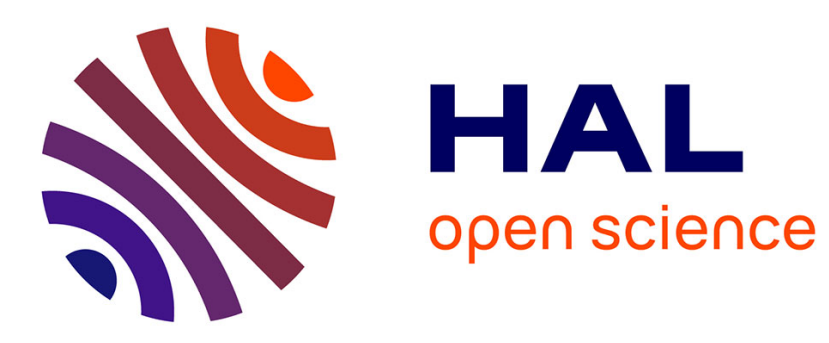

\title{
Two decades of research on innovation in services: Which place for public services?
}

\author{
Faridah Djellal, Faïz Gallouj, Ian Miles
}

\section{To cite this version:}

Faridah Djellal, Faïz Gallouj, Ian Miles. Two decades of research on innovation in services: Which place for public services?. Structural Change and Economic Dynamics, 2013, pp.98-117. 10.1016/j.strueco.2013.06.005 . halshs-01133837

\section{HAL Id: halshs-01133837 https://shs.hal.science/halshs-01133837}

Submitted on 20 Mar 2015

HAL is a multi-disciplinary open access archive for the deposit and dissemination of scientific research documents, whether they are published or not. The documents may come from teaching and research institutions in France or abroad, or from public or private research centers.
L'archive ouverte pluridisciplinaire HAL, est destinée au dépôt et à la diffusion de documents scientifiques de niveau recherche, publiés ou non, émanant des établissements d'enseignement et de recherche français ou étrangers, des laboratoires publics ou privés. 
Two decades of research on innovation in services: which place for public services?

Faridah Djellal $^{1}$, Faïz Gallouj ${ }^{1}$ and Ian Miles $^{2}$

${ }^{1}$ Clersé, University Lille 1

${ }^{2}$ Laboratory for the Economics of Innovation, HSE, Moscow ${ }^{1}$, and MIoIR, MBS, University of Manchester

\begin{abstract}
(Published in Structural Change and Economic Dynamics: DJELLAL F., GALLOUJ F., MILES I. (2013), Two decades of research on innovation in services: Which place for public services? Structural Change and Economic Dynamics, Vol. 27, December, 98-117.)
\end{abstract}

\begin{abstract}
:
Service innovation was neglected for a long time, but by the first years of this century it was clear that some maturity had been reached. Innovation in the public sector has been even more neglected in the mainstream of innovation studies. This paper explores the scope for fruitful integration of work on this topic into innovation studies more generally. It examines four different theoretical perspectives used in studies of service innovation: assimilation, demarcation, inversion and integration/synthesis. Each of these throws light on particular issues confronting public services innovation, and we see that innovation in this sphere is highly diverse and that it does often display special features. But we conclude that these features do not constitute a strong case for studying public service innovation as if it were something sui generis, let alone continuing to neglect it. Instead, the case is made for developing more integrative views of innovation.
\end{abstract}

\title{
Introduction
}

Innovation studies rapidly grew as an area of research over the last quarter of the twentieth century, as has been discussed at length by authors such as Fagerberg (2004) and Godin (2010). Several handbooks have sought to provide overviews of the field (for example Dodgson and Rothwell, 1994; Fagerberg et al., 2004), and there are numerous reviews of specialised topics such as the economics, sociology, and measurement of innovation, as well as huge bodies of work on innovation management and policy. It has been often remarked that research has been dominated by a focus on manufacturing industry, and in particular by rather "high-tech" industries such as aerospace, automotive and pharmaceuticals. Service innovation was neglected for a long time, but by the first years of this century it was clear that some maturity had been reached (Miles, 2000), to the point that a Handbook of Innovation and Services was published in 2010 (Gallouj and Djellal, 2010). Innovation in the public sector has been even more neglected in the mainstream of innovation studies, and this paper will

\footnotetext{
${ }^{1}$ Ian Miles contribution to this paper was carried out within the framework of the Basic Research Program of the Higher School of Economics in 2011-2012.
} 
attempt to explore the scope for fruitful integration of work on this topic into innovation studies more generally.

In addition to public services (and more generally non-market services) being more or less monopolies that are largely free from competitive pressures, several other reasons are habitually advanced for their having little to do with innovation. They are under political influence, which puts them on the margin of the rationalistic economics of innovation ${ }^{2}$. They often suffer from lack of resources, of resources that can be devoted to risky innovation projects, and of incentives for innovators and intrapreneurs. There is little pressure from consumers of the services, or else this pressure is dispersed by the rigid bureaucratic structures that induce inertia in the public sector. Professional groups like doctors and teachers may impede innovation that undermines their privileged positions. And so on... Exceptions of course do have to be recognised, especially where basic research in Universities and laboratories can be a source of new knowledge and creative ideas as to how to apply it though the large-scale uptake and further development of such applications is generally seen as the preserve of private firms.

But, conversely, many arguments qualify or contradict this negative assessment of innovation in public services, and imply that we should raise their status in the field of service innovation studies. Here is a brief review of some of these arguments:

- It is paradoxical to believe that public administrations are ambivalent: eager to support innovation, but ignoring innovation on their own behalf. Indeed, the upsurge of activity around e-government indicates that many regimes are intent upon using new technologies to improve internal processes and links to their citizens. An intriguing hypothesis would be that an administration that is innovative for itself will be more effective in supporting innovation for other economic agents. We could suggest comparative analysis of the relationship between efforts to modernise public administration (through e-government and other initiatives) and those aimed at innovation policies more generally.

- Within public services, there are sectors whose innovation activities are indisputable and well documented in literature of various kinds - though not always in innovation studies (Rosenberg and Nelson, 1994; Djellal and Gallouj, 2007). In addition to Universities and public research laboratories, we might mention health services, public broadcasting services, and the security and defence services.

- The perimeters of public services and private services are fluctuating in space and time. In fact there has often been competition between public and private services, varying over countries and periods. Some highly innovative private services - such as telecommunications - were historically state-owned enterprises until the last quarter of the twentieth century in many Western countries. The design and delivery of some public services is outsourced to private providers or provided through public-private partnerships (PPPs); and some backoffice functions in public services may be outsourced or subject to competition from various providers.

- The economic crisis and demographic changes are also an important factor for innovation in public services, since they lead to pressures for rationalisation of production as well as some efforts to reduce social expenditure - while meanwhile new or more intense social demands are emerging around, for example, eldercare and environmental issues.

There have been several recent reviews of the literature on innovation in service industries (e.g. Gallouj and Djellal, 2010, Miles, 2010). We will examine how the major studies conducted during two decades of research on innovation in services explicitly address, or can

\footnotetext{
${ }^{2}$ Even worse, in some circumstances, this influence is highly associated with clientalism and outright corruption, phenomena that are regularly discounted when it comes to market services.
} 
be extrapolated to address, innovation in public services. We also seek to identify shortfalls in this literature and determine new avenues of research and action.

The field of "service innovation studies" involves four different theoretical perspectives: assimilation, demarcation, inversion and integration (cf. Gallouj, 1998; Gallouj and Weinstein, 1997; Coombs and Miles 2000; Droege et al., 2009, and other authors cited in the latter study). These go under slightly different labels for different authors, but the common aim is to reflect different conceptions of the relationship of service innovation studies vis-àvis the established field of innovation studies, with its emphasis on manufacturing sectors and their products (see Figure 1). The assimilation perspective analyses innovation in service industries as essentially being the same as innovation in manufacturing industries, with service innovation then being much like goods innovation (indeed, services are just "intangible goods"). It focuses on their relationships with technological systems. This latter emphasis means that this can also be seen as a technologistic perspective (though, as we shall see, one line of research argued that service industries innovation trajectories around new technologies tend to be distinctive ones). Insofar as it mainly focuses on innovation adopted from manufacturing sectors, the assimilation perspective is also a subordination one, where it is new technologies developed in manufacturing that are assimilated into service industries. 


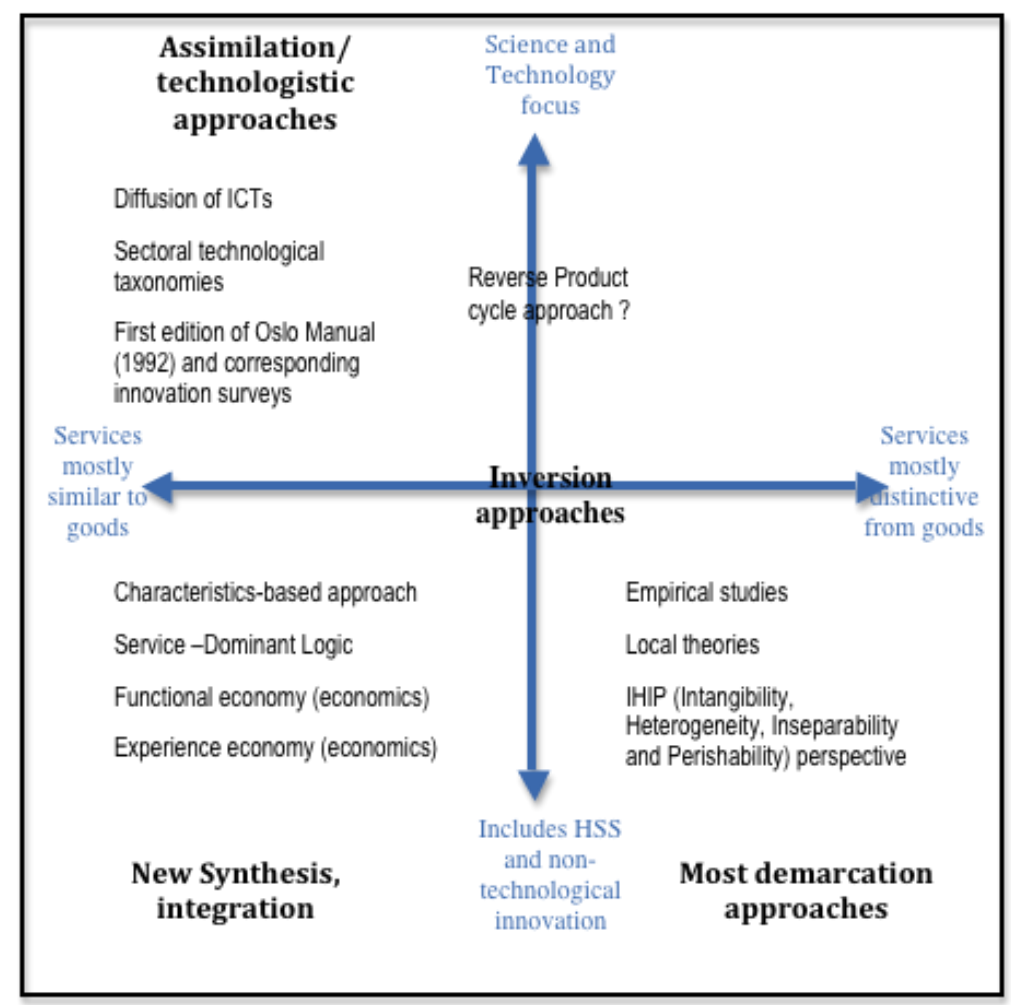

Figure 1: Innovation in services: different analytical perspectives

The differentiation (or demarcation) perspective focuses on services' specificities. Often inspired by case study work in service marketing and operations management, and in new service development, it often claims to identify innovation activity where the assimilation or technologist gaze perceives nothing. It stresses the different forms that innovation can take, and the distinctive organisation of innovation processes in service industries.

The inversion perspective (Gallouj, 2010) could be seen as the "revenge" of the service sector. In contrast to accounts that portray service industries as lagging sectors, whether this is a matter of being like low-tech manufacturing or something more distinctive, the inversion approach sees (some) service industries as being sources of innovation across the whole economy. One such role can be played by large service firms that mobilise their suppliers (e.g. in retail and telecommunications), but more often this perspective emphasises the active role of certain KIBS (Knowledge-Intensive Business Services) in other sectors' innovations. Consultancy, design, engineering, information technology and Research and Development services can be important inputs to innovation among their clients.

Finally, the integrative or synthesis perspective seeks to provide the same analytical frameworks for both goods and services products, for manufacturing and service industries, 
and for both technological and non-technological forms of innovation. From this viewpoint, we can draw on the points of similarity and of contrast across such dichotomies in order to deepen our understanding of innovation processes and practices. This is seen to be of great importance in a world where manufacturers are purportedly "servicising" and service firms "productising", where major economic projects and social functions involve combinations of goods and services, of technological and organisational change, and so on (Stahel, 1997; Pine and Gilmore, 1999; Davies, 2004; Vargo and Lusch, 2006).

We draw on these four theoretical perspectives to provide the structure of this paper, and suggest how public services are, or can be, addressed using the assimilation, demarcation, inversion and integration/synthesis approaches. The case will be made that this is not just of local interest to researchers into, and practitioners of, public services. It can help deepen and enrich innovation studies, and the analysis of contemporary economies, more generally.

\section{Public services and technological innovation: the assimilationist perspective}

Much of the early work in the field of "service innovation studies" took the perspective that we have labelled as technologistic, industrialistic or assimilationist (Gallouj, 1998, see also Coombs and Miles, 2000). This perspective naturally uses the tools inherited from the field of industrial innovation without considering the special nature of services. Thus, in essence, innovation is considered in its relations to material technical systems (their production and diffusion). For example, when Gershuny and Miles were first reviewing the transformation of contemporary service economies some thirty years ago (Gershuny and Miles, 1983), practically the sole focus was the use of new information technologies (IT) in service industries. Miles later extended this approach to suggest that different classes of service industry are shaped distinctively through the application of different types of technology (so those whose main products are informational are revolutionised by the application of new IT, while those - like transport - where the products are physical transformations feature applications of motor technologies, and human services - like health - feature many specific technologies, such as pharmaceuticals and surgical devices that address biological complexities) (cf. Miles, 1993).

The assimilation perspective is largely dominant in the literature. The conception of innovation that it conveys was reflected in the innovation indicators used in the first edition of the Oslo Manual (OECD, 1992; see also section 2.3).

Three varieties of the assimilationist perspective can be identified (cf. Figure 1). The first group, by far the most prolific and the most heterogeneous, brings together primarily empirical work devoted to analyzing the diffusion of exogenous technology into services, and the conditions and consequences of this. The other two groups bring together more theoretical studies (still very few in number), mainly belonging to the tradition of evolutionary economics. These involve, firstly, the reverse cycle model of Barras (1986, 1990), and, secondly, sectoral taxonomies that trace distinctive modes of innovation in various service industries. We will review these three sets of studies, in the light of the issue of innovation in public services.

\subsection{Innovation indicators: a technological bias still prevalent}


The conception of innovation associated with the assimilation perspective is reflected in the innovation indicators suggested by OECD Oslo Manual (the most recent revision of this is OECD, 2005). This most recent revision includes definitions and questions about organisational and marketing innovation, as well as product and process innovations. It has dropped the prefix "technological" from its definitions of product and process innovation, though the examples of these sorts of innovation are mainly technology-based, and those that do not involve technological innovation as such still seem highly oriented around technology. Of course, very few (mainly personal) services are simply a matter of person-to-person contact, with no application of, or mediation by, material technologies. Indeed, the majority of marketed service products in modern industrial societies involve service workers using material artefacts that were uncommon before the twentieth century - automotives, computers, telecommunications systems, specialised electronic devices (cash registers, scales, amplifiers, and so on). The Oslo examples (in Chapter 3 of the Manual) almost all imply application of novel hardware and software - about the only exceptions are innovations centred on the location of services (home delivery and pick-up of rented vehicles, provision of management contact points for outsourced services on-site rather than remotely), or application of techniques which in practice are likely to involve new technology support (the implementation of a new reservation and projects management system are mentioned). Thus, while in principle the Manual does not exclude non-technological product innovation (for example a new insurance contract or a new financial product, a new field of expertise in consultancy), or non-technological process innovation (methodologies, protocols), the formulations tend to work against inclusion of such cases. There is limited guidance provided in the actual CIS questionnaires to help those completing the surveys with these details.

It is admitted in the Oslo Manual (revision 3, 2005) that product and process innovation may be hard to differentiate in service activities, but there is little consideration of a further point that ad hoc and tailor-made innovation are prevalent in some services (see section 2) notably many KIBS such as engineering and consultancy services. It remains to be seen how far respondents to Innovation surveys classify such service products - are they seen as significantly different or improved products or as simply further examples of the same broad product class?

Just as R\&D surveys tend to dismiss $R \& D$ that does not focus on natural sciences and engineering (even though social science $R \& D$ is explicitly ruled in by the Frascati Manual) (Djellal et al., 2003; Miles, 2007), so innovation surveys tend to neglect non-technological product and process innovation (when it is not classified as organisational or marketing innovation). This may help account for the apparently low levels of innovation reported by many services sectors - indeed by most of those not engaged in technological innovation; the exceptions tend to be technology-based service organisations such as software firms and R\&D and engineering services.

\subsection{Innovation in services and the diffusion of (information) technologies}

Whether at the microeconomic or macroeconomic level, discussions of innovation in services have long been preoccupied by the introduction of new technologies - especially with the pervasive introduction of new IT across practically all service industries over the past four decades, and the changes in business organisation associated with the use of these technologies. The high level of uptake of new IT by service sectors was noted by researchers 
such as Roach (1987), OECD (1993), who noted that service sectors invested in more of this equipment than would be expected given their share of national economies.

The historical diffusion of IT in services is often described, rather simplistically, through a succession of overlapping generations of innovation, the first based on mainframe computing, the second on personal computing, and third and later on networking and mobile and ubiquitous IT (Gallouj, 2002a; Miles, 2005). Much economic research tends to treat different generations of technology as essentially similar, or at least as differing in terms of easily specified hedonic parameters. For given institutional contexts, much of the literature is therefore devoted to the discussion of the relationship between use of new IT and a number of fundamental economic variables such as employment, productivity, skills and task organisation, the tradable nature and quality of the service product, etc. Management studies, meanwhile, pays more attention to generational change, typically celebrating the novel features of emerging generations. In this case, more attention is paid to how the economic variables may be reshaped in different generations of technology.

The literature on the introduction of new IT in public organisations fits perfectly in this framework crossing innovation models and economic variables. Back office computerisation was aimed at productivity and efficiency gains through heavy "number-crunching" mainframe systems. Public administration was a pioneering user of these systems, used for processing large volumes of information about, for example, pensions and welfare benefits. At roughly the same time, financial service firms - again dealing with information concerning many features of many individuals - were undertaking similar automation. These systems speeded up the processing of cases, and helped reduce costs by standardising tasks and achieving economies of scale. Subsequent computers, and associated software, enabled both cost reduction and increased quality; economies of scope were enabled. As new IT became increasingly visible in the early 1980s, considerable concern was expressed by trades unions and others, that massive job displacement and deskilling would ensue. Many studies analyze its ability to re-skill the workforce (increasing the variety of tasks performed) and to improve front-office service quality to users, especially in terms of speed, availability at a distance and out of office hours, and integration of services in one-stop shops. There is, however, growing concern that new IT has enabled the automation of many more routine clerical and symbolprocessing jobs, and (along with management strategies of organisational hollowing and outsourcing) contributed to the polarisation of the workforce (in the increased disparity between top and low-level wages, and the reduction in middle-level positions - cf. Autor et al., 2003). Other interesting examples of innovations in public services linked to ICTs are system level applications such as intelligent traffic and smart grids. One important issue, not addressed in the case of services in general, but which is relevant when it comes to the relationship between the introduction of new IT and public services, is the digital divide (Attour and Longhi, 2009) - the idea that social disadvantage may be amplified through differential access to new IT (especially online services) across regions, social classes, generations, etc. This is important in relation to the specific missions of public services which (a) may be concerned about unequal access to, for example, e-government services (this could even be used as an argument against rapidly shifting to online provision) and (b) may seek to offset digital divides through education (school curricula including courses in IT use) and public facilities (libraries offering free Internet access). We see social innovations such as "electronic village halls" in this context. 


\subsection{The reverse product cycle model: a glimpse of innovation in public services}

The reverse cycle approach (Barras, 1986, 1990; Gallouj, 1998) is a specific articulation of the "innovation models"/generations of new IT account sketched in above, which deserves special attention for at least two reasons. First, it represents the first attempt to construct a theory of innovation in service industries, and as such it was, and continues to be, extensively cited in the literature. The basic ideas are rather plausible - if not always borne out in subsequent empirics. Second, the approach was developed on the basis of empirical research involving not only market services, but also public services (especially local government services).

Barras' approach is actually not really a general theory of innovation in service sectors, since he does not consider all sorts of innovation in these industries - his account has little to say, for example, about transport or medical innovations. It is more an account of the diffusion of new IT from manufacturing to service industries - but it goes beyond diffusion, to consider the learning processes associated with, and subsequent to, this. The traditional product cycle approach describes a succession of stages in the development of an innovation (Abernathy and Utterback, 1978). Putting this in the most rudimentary form, these are characterised by a period where product innovation is the main focus, until a dominant design is stabilised; then there is a shift to a period where process innovation is increasingly the main focus, as competition moves away from providing the best type of product towards providing the product most efficiently. In Barras' account, the cycle of service innovation is distinctive. Its first two phases mainly involve incremental and radical process innovation, and in its final phase is dominated by product innovation. This could be depicted as a learning process, wherein the service organisation comes to better understand the potential functionality of the new technologies it is using. It thus becomes able to master these and elaborate on its own specific applications, including new service products and delivery methods.

This account of back-office information-processing innovations could plausibly be extended beyond the service sector, it should be noted. Organisations of all kinds can find new backoffice capabilities to be enabling a range of innovations in other business processes. Customer service and supply chain management processes are one obvious example, but there are cases that come closer to product innovation. For example, one publisher of art and educational books found that it could offer new collections as a result of automating its indexing and other databases.

Barras was not just observing learning about a particular set of technologies. He was also observing change in the course of the shift from mainframe to personal computing (and, to some extent, networking). He thus described the phases of the reverse product cycle in relation to new generations of IT, corresponding to the different waves of computerisation mentioned in the previous paragraph. The initial back-office process innovation is very much a matter of mainframe systems, while the later service innovations increasingly involve personal computing and data communication networks. Barras illustrated his account with examples of mass services whose activity is centred on information processing, and while his later work emphasised financial services as the vanguard of the IT revolution, his earlier work included examples of administrative public services.

The first wave of computerisation (introduction of mainframes) resulted in incremental process innovations in the back office activities of this type of public service organisation, to increase efficiency and speed, and, especially, to reduce costs. One example is the 
computerisation of personnel records and salaries in both public and market services. However, it should be noted that the organisational change - from armies of clerks (in typing pools, for example) to huge computer systems with (at first) many data entry staff - was far from incremental. There was often change in physical locations (computer centres were distant from head offices), in the organisation of work flows, in the creation of new jobs technicians and programmers as well as data entry staff - and numerous modifications in, for example, the sorts of paper used, the printing equipment, the ways in which results were validated and communicated. Large public service organisations were lead users of this sort of computerisation.

The second wave of computerisation (involving mini and microcomputers, which could more readily be located close to users) resulted in more radical process innovations involving the front-office functions of the administrations. The aim of these innovations was to improve effectiveness and quality of service. Examples include providing online administrative information or administrative forms, online registration for public procurement procedures, computerised management of housing waiting lists at city offices (even if the communications with citizens were accomplished by telephone or by staff who were augmented with PCs), and automated ticket machines (galleries, museums, other public services).

Later waves of computerisation, in the case of public services, have naturally made use of successive improvements in PCs, but more important is their use of networks for email and information access, and for interactive services. Mobile and smartphone apps have emerged relatively belatedly (perhaps because the lack of dominant standards here makes it difficult for public services to innovate without apparently displaying favouritism to one or other contender in the standards wars).

Barras considered online delivery of public services to represent product innovations (which corresponds to the Oslo Manual understanding). Examples include advanced moves to egovernment, where access to many administrative procedures is made available online, and there are even moves to e-democracy. This form of e-government essentially aims "to dematerialise the traditional administrative procedures" (Suire, 2007). For example in France, the Family Welfare Office (CAF) has a website where users can declare their income, access forms and track the status of their payments and reimbursements. The French National Health Insurance System (CNAM) also has a website where users can access information, forms and track online reimbursements (Bacache-Beauvallet et al. 2011). Arduini et al. (2010) examine the development and the forms of e-government in Italian cities, based on a number of contextual variables. In the UK, the government provides facilities for citizens to create petitions, with the idea that topics that gather a great deal of support may be taken forward for parliamentary debate.

Such (mostly recent) developments in e-government provide new perspectives on this third phase of the cycle that enrich and strengthen Barras' initial model.

- Some of these innovations establish stronger interaction between administrations and users and that give users a more active role in creating these services (in accordance with the spirit of Web 2.0). These innovations reflect an evolution from e-government focused on dematerialisation and efficiency, to a richer e-governance seeking "to change the nature of the relationship by initiating a new form of more interactive partnership with the citizen-user" (Suire, 2007).

- In its third phase, Barras' model focuses primarily on e-services provided to the client or end user (in the case of public services, G2C). One can easily extend the model to include other 
recipients: businesses (G2B) - indeed, many public services are aimed at industry, not least support for various innovation activities - and other government agencies $(\mathrm{G} 2 \mathrm{G})$ - which can include horizontal service relationships (with other public agencies) and vertical ones (with higher or lower administrative levels).

It may seem paradoxical that Barras' reverse product cycle approach highlights a specific behaviour of service organisations in terms of innovation (they have a reverse cycle), but that we here locate it as an assimilationist approach (rather than a differentiating approach, as did Coombs and Miles, 2000). The explanation is that although the cycle is reversed, Barras describes an exclusively technological innovation dynamic (for example, public services provide e-government and online delivery of information and forms). There is little attention to new non-technological services that may be created, such as new social policies, like pension entitlements, citizen rights, ombudsman procedures, and the like. Indeed, there are dramatic new technology-enabled services that can also be created, but which require considerable development of appropriate business models and social support - for example new services in support of active independent living that employ new systems for monitoring the health of vulnerable people. Another evidence of the technologist bias of Barras' framework is that new financial products are not given as examples of product innovation in banking. The only examples given (e-banking) are technology-based.

The privileging of technological innovation is not the only limitation of this approach - and not only when it is applied to public services. Uchupalanan (2000) studied a range of IT innovations across Thai banks in some detail, and concluded that IT innovation in services can follow various paths, with the reverse product cycle pattern being just one, fairly unusual, case. This is relevant to public services, where innovations may be triggered by many factors. For example, much of the diffusion of e-government practice around the world is more to do with policymakers seeking to imitate and even surpass service innovations undertaken elsewhere, than with administrators discovering new things to do with their computer systems. Public service technological innovation can even be a matter of pressure from users - for example, patients using the web to find information about treatments, and then pressuring their doctors to assess and provide these treatments themselves. Another case that will be familiar to academics is the introduction of anti-plagiarism software, in response to students "borrowing" essay material from Internet sources,

Much of the power of the reverse product cycle approach comes from its reliance upon the traditional product/process distinction; this is problematic in services, as the Oslo Manual notes. The two dimensions are often inseparable because the product is defined as an act - and at least the front-office part of the service production process is liable to be coterminal with the consumption of the service (Gallouj, 1998).

Finally, even were the Barras account to be accurate, it would still be incomplete, in that it focuses on technological innovation and "a theory of innovation in services" should include non-technological service innovation. Furthermore, its technological orientation is itself limited, insofar as it focuses exclusively on IT-based innovation. But services in general, not least public services, can and do use other types of technologies, for instance physical, chemical or biotechnological systems (cooking, refrigeration, transportation, handling goods; and the host of tools used in public services such as health, services, including medicines, surgical and dental equipment, prostheses, and more.). Even in terms of IT-based innovation, there are limitations. Barras' approach very much describes the experience of service organisations at a particular historical period, when they are first adopting and learning to use 
new IT. Twenty-five years on, later generations of IT innovation might well bring different patterns into play. Likewise, as service organisations have successfully assimilated new IT and moved to product innovations enabled by the technology, would they be expected to continue on a reverse product cycle track - or to come to resemble organisations in other sectors, conforming more closely to the established product cycle approach.

\subsection{Sectoral patterns of technological innovation}

It has long been evident that innovation patterns vary across economic sectors. Pavitt (1984) introduced a highly influential classification framework, in which he located various industrial sectors into various categories in terms of technological innovation. In his original formulation, all service sectors were seen as falling into a "supplier-driven" category ${ }^{3}$. Pavitt's treatment of service sectors reflects the prevalent view, until the 1990s, that innovation can be identified with technological innovations, which mainly flow from manufacturing industries.

Soete and Miozzo (1989) accepted Pavitt's focus on technological innovation. But they revised his innovation taxonomy, demonstrating that with slight adaptation, the Pavitt categories could be applied to differentiating within service industries. This implied that even if many service sectors are still supplier-driven, this is not the case for all of them; indeed, the range of innovative practices across service businesses is as wide as that seen in manufacturing.

Soete and Miozzo see many services sectors as being largely supplier dominated, mentioning personal services (food \& drink, repair businesses, hairdressers, etc.), together with the retail trade. Some services belong, in contrast, to production-intensive, scale-intensive sectors whose large-scale back-office administrative tasks are often amenable to some automation through application of new IT. Network sectors are also large-scale; some are dependent on extensive physical networks (e.g. transport and travel services, wholesale trade and distribution), others on informational networks (e.g. banks, insurance, broadcasting and telecommunications). Such services are important in shaping IT networks, and play a major role in defining and specifying innovations, rather than being passive users. Another category is specialised technology suppliers and science-based sectors, such as software and specialised business services, laboratory and design services, where the main source of technology is the businesses' own innovative activity and the innovation process tends to be "user dominated".

While the Soete/Miozzo account was largely impressionistic, some recent studies have used innovation survey data to develop and explore rather similar classification systems. Thus one German study Hipp and Grupp (2005) differentiated between four patterns - the knowledgeintensive, network-intensive, scale-intensive and external innovation-intensive patterns. These are very similar to the Soete/Miozzo and Pavitt categories, but since they work with firm-level data, these authors can establish another important point. Apart from confirming the diversity of innovation types among services, their results warn against identifying service sectors with service innovation patterns. Certainly the patterns and service industry sectors are related - for example, the knowledge-intensive pattern was particularly common in technical

\footnotetext{
${ }^{3}$ Notably, the empirical work on which his framework was constructed was derived from a database of innovations that did not seek to cover service sectors.
} 
KIBS, the network-based pattern in banking, the supplier-dominated pattern in other financial services. But all sectors featured several of the patterns. Companies that nominally belong to the same sector can thus have quite different innovation patterns, a point elided in many studies of service innovation.

As with practically all innovation survey studies, the Hipp and Grupp study only concerned private sector services. In their more impressionistic analysis, Soete and Miozzo did considered public services (education, health care, administration). Their view was that these lie within the supplier-dominated category, though there is little evidence marshalled to support this account. Certainly these are sectors that consume large volumes of technologies from outside sources - all apply IT extensively, while health in particular makes use of many specialised innovations from manufacturing (pharmaceuticals, surgical equipment, and the like). But these are also services with considerable resemblance to the large network service organisations in the private sector. There are obvious analogies between surgeries, hospitals, schools, colleges, employment and social security centres, and the like, and the branches of banks, supermarkets and other such bodies, and between the large back-office facilities in public administration and those in financial services. Government computer centres were in fact lead users of mainframes and data networks.

There are also striking dissimilarities between many of these large public services and their private sector equivalents. Unlike banking and retail services, for example, health and education services have very "knowledge-intensive" workforces - at least assessed by high shares of graduates among their employees. Public administration appears to have an usually large share of "information workers", with higher school education but without University degrees $^{4}$. It is evident that different public services have different knowledge bases, and relate to citizens in quite different ways - compare school police, hospital and tax services, for example. It is thus to be expected that public services will vary one from another (and over time). But many national-level public services are liable to resemble scale and networkintensive sectors in several respects. We can also expect some services to have a lot in common with the knowledge-intensive pattern, since we see R\&D departments and programmes, laboratories and service design efforts, in many public service sectors (at least in larger and wealthier countries). Thus it is implausible that public services can be readily seen as simply following supplier-driven or external innovation patterns. Whether we need to introduce new patterns into the classification system, or can fit public services more or less adequately into the categories discussed above, remains to be seen.

Indeed, it may not only be sectors that are internally heterogeneous. Different innovation patterns and trajectories can coexist and interact within the same organisations (cf. for example, Gallouj, 2002a). There are very many examples of the hybridisation of logistical and material processing trajectories and logistical and information processing trajectories in hospitals. The following can be cited as examples of hybrid medical technologies (that is technologies that combine ICTs with more traditional, material processing technologies): computer-aided diagnostics, medical supervision, automated diagnostic equipment, video surgery. There can, for example, be different patterns for the technological trajectories of material or information processing, and those more concerned with service and relational (non-technological) trajectories. For example, one important innovation in mental health services the U.K. has been the wide introduction of cognitive-behavioural therapy, sometimes

\footnotetext{
${ }^{4}$ Miles (2008) includes data on educational credentials as part of a series of statistical contrasts across service sectors.
} 
in conjunction with pharmaceuticals, sometimes on a stand-alone basis. This therapy is very much a matter of deploying new approaches that encourage clients to review and reconsider their thinking patterns, and to apply different cognitive strategies in facing issues in their lives. It could be seen as equipping the health service staff with new routines and scripts that they can use to encourage new routines among their clients. The effects are evaluated as being comparable with or superior to antidepressants. Furthermore, the procedures are being used in schools and employment services, as well as in health services (Platts and Williamson, 2000; Winspear and Robertson, 2005). CBT is often used in conjunction with pharmaceuticals, or is delivered through IT media. This is just one example. The point is that various technological and non-technological trajectories can coexist separately or in hybrid fashion, in private or public service organisations (Djellal and Gallouj, 2005, 2008).

\subsection{Assimilationist perspective and industrialisation (or industrial rationalisation) of services}

The assimilationist perspective can be interpreted as attempting to see services as differing minimally from goods, and thus as easy to address with innovation studies' established theoretical frameworks and metrics. This intellectual effort finds a parallel in (service) industrial management. This focuses on making service products more like "normal" products (often just called "products - thus we hear of the "productisation of services"). This means standardisation of services, so essentially the same service product can be replicated many times over with minimal variations. The products is made less fuzzy, the interaction between service provider and client (i.e., the service relationship) is reduced to a minimum (Levitt, 1976). However, it should be noted that in the new visions of productisation (cf. for example Valminen, 2011, Valminen and Toivonen, 2011), while the purpose is still to make the service less fuzzy, instead of the interaction between the customer and the service provider being minimised, it is actually fostered, especially thanks to ICTs.

One of the earliest discussions contributing to the service innovation literatures was made by Levitt (1976), who argued that service organisations were expanding in scale by adopting industrial processes (such as high division of labour, reduction in the need for craft skills) and standardising their products to achieve scale economies. This was echoed in Barras' studies, where he remarked that new IT was promoting an industrial revolution in service sectors - but Levitt, talking of "hard", "soft" and "hybrid" technologies, was looking at a wider range of technological and procedural reorganisation in services, including the organisation of standard products in the fast food and retail industries, for example. On the other hand, analyses of flexible, post-Fordist forms of industrialisation were still nascent at this time, and we would now point to "Mass customisation" and "flexible specialisation" in activities such as fast food (where a huge variety of food products can be assembled out of a set of standard modular components) (Gadrey, 1996; Jiao et al, 2003; Sundbo, 2002).

From this standpoint, the assimilationist perspective is not only present in the literature - it is being applied in many service organisations, including in public services. The assumption that work is best done in the context of strongly hierarchical, segmented bureaucracies governed by rules is not unfamiliar in public services. This form of rationalisation, which reduces diversity (and ad hoc or tailor-made innovation) is considered to be a source of efficiency (thus we see surgeons being encouraged to specialise on conducting a particular operation within a high division of labour). But it can also be advocated as a basis for better equity, 
since it implies that identical public services are being provided for everyone, everywhere in a society.

It should also be noted that the industrialisation model for public services is very much aligned with the rise of "new public management" thinking over recent decades, which argued that public services would be most likely to innovate and become efficient if they adopted organisational structures such as they prevail in private services - including more internal marketisation, more outsourcing of services, more competitive pressures, targets and performance measurement indices, and so on. At the same time, criticism of this approach as failing to address substantive issues of service design and service quality has emerged. (For an extensive critique, see Seddon, 2008.) The concern is that industrialised services may risk losing much of the service relationship that can effect growth and development on the part of the service client, a concern that will be familiar to many in higher education.

\subsection{A partial loosening of the assimilationist perspective? Autonomisation and endogenisation}

The assimilationist perspective has been loosened in various ways, especially in more recent research. This loosening has two main forms, each of which implies a shift of perspective away from seeing service sectors as low-tech, supplier-led industries - while retaining the view that they can be fundamentally well-described by the industrial innovation paradigm.

The first loosening we can label autonomisation, in that service organisations are less likely to be seen as subordinate to industrial innovation. Some service organisations - public services as well as private ones - are no longer seen as being locked into passive adoption of technologies produced elsewhere. In certain cases, they can produce some of these techniques themselves, but more importantly, they can sometimes reverse the power relationship by exercising a decisive influence on industrial suppliers of equipment and effectively directing the technological trajectories (by imposing functional and technical specifications, etc.). In some cases, there may be a complete reversal of the power relationship, generating innovation trajectories that are no longer "supplier-dominated," but "consumer or user-dominated" (see Section 3 below). Note that this account applies to general public services - there are also specialised public service activities that conduct R\&D and may well produce scientific discoveries and technological innovations (research laboratories, University research groups, health service laboratories, etc.). They are fundamentally autonomous, and some aspects of industrial innovation models can be applied to them - and with the privatisation of many government laboratories in several countries (OECD 2011), this has been effected in practice, not just in academic analysis.

The second loosening of the assimilationist perspective we can label the endogenisation of IT innovation, arguably, has the greatest effect on service industries in general, and on public services in particular. The introduction of IT at all levels of service organisations (back office and front office) is helping to change the nature of the product. Services and innovation in services appear increasingly as hybrid categories combining tangible and intangible IT and organisational engineering, that is to say, design and development of organisational forms (Djellal et al., 2003). This endogenisation of IT leads to new forms of interactivity and new spaces (national or international virtual proximity, etc.).

The assimilationist perspective allows for diversity across services, and can take account of trends in service innovation that demonstrate not only industrialisation, but also at least partial 
autonomisation and endogenisation of IT innovation across service industries. But other writers stress the distinctiveness of services, and what we label the differentiation perspective is still active - its implications for public services will be considered in the next section.

\section{Differentiation: the specificities of innovation in services}

The second analytical perspective has several labels in the literature: "service-oriented" or "differentiation" perspective (Gallouj and Weinstein, 1997), the "demarcation" perspective (Coombs and Miles, 2000) or "distinction" perspective (Salter and Tether, 2006). Despite the diversity of labels, the authors share similar ideas about this perspective. It is seen as focusing on the specificities of service innovation (its nature, organisation, determinants and ownership regimes), where the idea is that there are forms of innovation that are neglected or even hidden, that may be identified via a focus on service activities. Much of this work takes the form of explicating the specificities of services, and considering their consequences for innovation and innovation measurement. Other studies are more inductive, representing efforts to assess actual cases of service innovation. It should be noted that the political science literature, which is often neglected by economics and management science, has contributed to this differentiation perspective, addressing either the nature of innovation or its modes of organisation and implementation. Just a few of these references are Moore (1995), Benington and Moore (2011), Osborne (2010), Hartley (2005), Sørensen and Torging (2012). In addition to empirically-based typologies, the demarcation perspective also provides more conceptual contributions which could be called 'local theories' of innovation in services (Gallouj, 2002a), as far as their aim is to identify sector-specific innovation behaviours without pretending to generalize them to the whole set of service activities. Such local theories, which we will not discuss here, are for example developed in the field of retailing: see for example the 'accordion theory' (Hollander, 1966) and the 'theory of the retailing wheel' (McNair, 1958).

\subsection{The specificities of services and their impact on innovation}

Numerous features are supposed to differentiate service activities and products from those seen as describing manufacturing and goods (Miles, 1993, laid out an extensive list of these and even then, failed to use the now-popular term "co-production"). Intangibility and interactivity are the two intrinsic technical characteristics generally ascribed to service products as differentiating them from goods. These provide a useful heuristic for deductively analyzing the impacts of the characteristics of service specificities on innovation.

The intangibility of services was noted by Adam Smith in The Wealth of Nations (Smith, 1776). Many services cannot be stored, and are consumed at the time and place of production (coterminality, colocation). The service product is not a tangible artefact, but more a change of state (Hill, 1977; Gadrey, 1992). These features often blur the traditional distinction between product innovation, process innovation and organisational innovation. But they should also draw our attention to forms of intangible product innovations that are not embedded in technical components. Much of the "ad hoc innovation" (Gadrey and Gallouj, 1998; Gallouj and Weinstein, 1997) that goes well beyond customisation takes this form. Equally, intangibility can be seen as something to be overcome by the service supplier, leading to "formalisation innovations" aimed at making the product more productised, more demonstrable, more transportable, and to add tangible elements to the service (such as loyalty cards, new media platforms). It is also difficult to protect intangible innovations using IPR 
mechanisms like patents, and at least some kinds of service innovation are relatively easily copied. Finally, intangibility can make it difficult to assess the economic impact of the innovation as far it is difficult to assess the impact of a blurred output which frontiers are not always well defined.

One helpful development in the services research literature in recent years has been the emphasis on the difference between front and back office. The front office (or front-stage in the work of Glushko - e.g. Glushko and Tabas (2009) - is the point at which service workers and customers interact and coproduce the service; it is the point at which service process and product are often hard to disentangle. The back office/back-stage is less visible to the user, as is implied by the theatrical terminology; it is where costumes are donned, actors are prepared. But there is a much more extensive "back-stage", including (for example) the rehearsal studio, the scriptwriting, the stage design work; the processes involved here are not usually coterminal and colocated with the performance and its consumption. Similarly in public services, teachers prepare their lessons and presentation material, laboratory staff in hospitals conduct medical tests and doctors discuss treatment options, social workers undertake case conferences, and the like. Additionally, there is the back office in which fairly universal processes of staff management and payroll, organisation of supply chains and schedules of service activities, maintaining customer records, and so on, are all managed. Glushko and Tabas (2009) discuss how new IT can be used to create new linkages between customers and activities that were customarily back-stage ones - an example being the ability to track the progress of packages being handled through freight transport systems. Public services can similarly provide their clients with improved intelligence about the status of their case within administrative systems, and other innovations can allow for improved interaction between clients and elements of the public service system that were previously invisible and unapproachable.

The second characteristic, interactivity, means that the consumer, customer or user is involved, in one way or another, in producing the service. This is very likely to impact upon innovation in services. Thus, coproduction, as it is now widely known, promotes forms of tailor-made and ad-hoc innovation. It implies an interactive organisation of innovation rather than a linear organisation. This raises issues of ownership of the product of collective work, and may create problems for the reproducibility of innovations - or even the accumulation of the knowledge generated in the course of the innovation process.

Those two characteristics - and thus the discussion of possible impacts on innovation - apply to public services as well as private services. Indeed, Adam Smith himself mentioned servants of the state as examples in his analysis of the specificities of services. However, public services are also "public", which may lead to the specific characteristics that have impacts on innovation. A "double differentiation" can apply - in addition to services differentiation vis-àvis industrial innovation, public services are differentiated vis-à-vis market services innovation. Three characteristics are often cited in this context, all of which have been touched upon earlier:

First, innovation studies have typically seen innovation as stimulated by competition between firms: why should public services innovate, without this spur? Scientific breakthroughs may emerge from public sector research, but it takes entrepreneurial initiative to turn discoveries and inventions into market-facing innovations. New Public Management is in part justified as bringing competition and quasi-markets into public services, and outsourcing arrangements 
and Public-Private Partnerships of various kinds are seen as bringing business rigour to service production and delivery.

Evidence on the relative innovation propensity of public and private services is mixed - see Halvorsen et al. (2005) - with at least one study finding higher rates of adoption of key innovations in public health and education services than in private comparators (Earl, 2002). But the received wisdom is that non-market, non-competitive nature of public services hinders their innovation. Bureaucratic organisations and their civil servants are said to have no incentive to innovate because they operate in protected or monopolistic environments. Indeed, public organisations are said to be strongly risk averse and reluctant to experiment or risk failure (even though learning may not be achieved without some failure). Concern for efficiency in public services is a source of innovation aimed at achieving rationalisation, but, as noted by a number of studies (Potts, 2009, Koch et al., 2005), it is also a barrier to other forms of innovation.

Some critical views of public sector managers see them as having objectives that do nothing to encourage efficiency and innovation. For example, their primary concern may be extending the scope of their power by increasing the number of people in their charge, increasing their budgets and spending capacity and focusing on the (new) most visible and most spectacular outputs at the expense of more useful but less visible ones (Lindsay, 1976). Such cases cannot be denied; but it should be noted that in contrast, many professional workers will have entered public service in order to help confront social problems, rather than to secure prestigious jobs and comfortable pensions; they are liable to be motivated to use their knowledge to find better ways of doing things. Bureaucracies may limit their scope for innovation; equally likely, many innovations in large public service innovations are not effectively diffused within these organisations (Greenhalgh et al., 2005).

Second, it is the political system, rather than shareholders, that maintains control of public services. Thus, the problems inherent in agency relationships are particularly acute in public services than in market services (Dixit, 2002): opportunities for control (by the ultimate owners who are citizens) and incentives to improve performance and innovate are considerably reduced. Much change in public services is a result of reorganisations imposed for ideological reasons or as hasty responses to media furore - though we should not ignore the existence of evidence-based efforts to learn from policy systems elsewhere (e.g. the diffusion of ombudsman systems, cf. Newmark, 2002). As well as new policies from the political masters, it is not unknown for top-down innovation to be imposed by senior management -without a full process of trialling with service staff and end-users. A recent example is the failure to realise large components of the world's biggest IT initiative, the NHS IT system, after huge expenditure, and after years of complaints of extensive failure to assess user requirements and properly listen to user views.

Third, the principles of public service (equality, fairness, continuity) are liable to impact innovation. Public service managers are obliged to adhere to rigid procedures that safeguard the principles of equality among citizens (in terms of location of infrastructure, recruitment, and so on), and often have limited freedom to substitute resources (Knox Lovell, 2002), and limited resources to spend on building or acquiring equipment. Concerning the nature of the product, as Fox (1999) notes, public services managers have no control over the mix of services provided, unlike their private sector counterparts. They have limited freedom to influence the nature of the product: for example, they cannot, on their own initiative, stop providing a service or offer a different one. 
The principles of public services can also stimulate innovation. They can lead to specific nontechnical and non-market forms of innovation, involving domestic, social and civic issues, that is to say which value interpersonal relationships, empathy, trust, concern for inclusion and equal treatment, and social-civic products. Thus, the rise of social innovation within or with the participation of public services is an important consequence of this third characteristic (which reflects the principles of public service: equality, fairness, continuity).

Thus there are good reasons to expect that the "double differentiation" of public services will impact their innovations to greater or lesser extents. The ways in which this happens are liable to vary across service types, and over time and countries. Exploring this issue is an important theme for comparative research.

\subsection{Empirical research and the classification of specific forms of innovation}

While there have been efforts, as discussed above, to derive specificities of service innovation from the specificities of service activities and products themselves, much empirical work is primarily inductive. Assuming that there will be distinctive features, it sets out to explore cases of service innovation with a more or less open mind as to what these will be. Technological innovations are not the only type of innovation being considered.

The first studies examined activities that resulted in highly intangible and interactive services, which are presumably ones where specificities are most likely to appear. They focused, for example, on "knowledge intensive business services" (KIBS), and on banking and insurance which also happened to be sectors where much early uptake of new IT was apparent. Furthermore, given the nature of their activity (knowledge processing), KIBS (especially consulting) could be particularly sensitive to the issue of innovation, either because they themselves innovate, or because they bring about innovation by their clients (Miles et al 1985). Den Hertog (2000), for example, discusses how KIBS innovate, and often share innovations with their clients, through fusing knowledge from these clients with their own more general knowledge bases - technological or otherwise. Gadrey and Gallouj (1998) suggested that the consultancies they examined practiced three forms of innovation: ad hoc innovation (original solutions to problems jointly developed with the client), new expertise field innovation (provision of advice in an emerging field of knowledge) and formalisation innovation (implementing methods to better define the service). A recent collection discussing such issues is di Maria et al. (2012).

Subsequently there was a sectoral shift of the analytical focus towards the specificities of innovations in services often considered more operational or less knowledge-intensive. Examples include hospitality, transportation, cleaning services, elderly care, etc. - sectors often studied from the perspective of service management and service quality, but less often seen in innovation terms.

Many ad hoc typologies have been developed in studies of the various activities, but one important feature is that such studies have repeatedly drawn attention to non-technological forms of innovation. Gadrey and Gallouj's (1998) three types of innovation are a case in point.

Similar empirical research from a demarcation perspective, focusing on possible specificities 
of service innovation has also been conducted on public services, especially in recent studies (Mulgan and Albury, 2003; Hartley, 2005; Koch et al., 2005; Windrum and Koch, 2008; Becheikh et al., 2009; Fuglsang, 2010; Miles, 2012). Among recent typologies of innovation in public services, we see - alongside the traditional categories of product/service, process, technological and organisational innovations - some specific forms of innovation. Halvorsen et al. (2005) also distinguish Administrative innovations (for example the use of a new policy instrument, which may be a result of policy change); System innovations (a new system or a fundamental change of an existing system, for instance by the establishment of new organisations or new patterns of co-operation and interaction); Conceptual innovations (a change in the outlook of actors; such changes are accompanied by the use of new concepts, for example integrated water management or mobility leasing); and even Radical changes of rationality (meaning that the world view or the mental matrix of the employees of an organisation is shifting). Hartley (2005) mentions innovations that involve Position (involving new contexts, customers or partners for services); Strategy (with new goals, purposes or values, such as involved in community policing); Governance (for example new democratic institutions and forms of participation); and Rhetoric (where new language, concepts and definitions are applied, as in congestion charging and carbon taxes). Bekkers et al. (2006) distinguish organisational innovations, that are focused on the creation of new organisational forms, or on the introduction of new management methods and techniques, and new working methods (e.g. shared service centres or new quality systems) from Conceptual innovations (involving new concepts, frames of reference or even new paradigms - New Public Management or the notion of governance might be examples); and from Institutional innovations (where there are fundamental transformations in the institutional relations between organisations, institutions, and other actors in the public sector - e.g. the introduction of elements of direct democracy, through referenda in a representative democracy). The various authors are using different terminology and making distinctions that differ in detail, but all point to a range of innovative activities that can occur at various levels in a public service framework. One aspect of this is the important role played by more general policy and governance frameworks, beyond the individual public service organisation itself.

\subsection{Indicators and surveys}

Much of the empirical research that stresses demarcation is qualitative - in part because the researchers seek to be open to new insights about types of innovation, and have suspected that the main instruments for surveying innovation at firm level to be inadequate. As we noted above, the Oslo Manual in its latest version (OECD, 2005), now includes marketing innovations and organisational innovations, in addition to product and process innovations. Successive Community Innovation Surveys (CIS) have opened up to more service industries and to certain "non-technological" forms of innovation, but there is still progress to be made, particularly in the areas of non-technological product innovations, non-technological process innovations, ad hoc innovations and tailor-made innovations, innovations in complex "packages" of goods and services, also known as new concepts or new formulas (for example, in retail, hospitality, etc.), social innovation, user innovation by consumers i.e. innovations introduced by consumers who develop or modify goods and services for their own use (Gault, 2012). (see section 1.1 above).

CIS and most other innovation surveys have typically been focused on the private sector, and thus, where services are covered, on marketed services. Just as efforts have been made to build innovation indicators tailored to services that take into account non-technological 
innovation, similar efforts are being made to cover public services. This raises such problems as identifying the appropriate entity for analysis (what level of government or a public service organisation, for example), and in dealing with the major differences among countries regarding the organisation of public services and their borders.

Indicators developed for sub-sectors of public services, such as the health sector (see Djellal and Gallouj 2005; Windrum and Koch, 2008), can be distinguished from broader indicators developed for all public services. One of the first (and still rare) national initiatives to measure innovation in public services is "the Korean Government Innovation Index," introduced in 2005 (APEC/Ministry of Public Administration and Security, 2005). More recently, in Europe, the recommendations of Clark et al. (2008) were implemented in 2011 (Hughes et al, 2011) as part of a pilot survey conducted in Britain in two sub-sectors: the NHS and Local Government. The MEPIN research project (Measuring Innovation in the Public Sector in the Nordic Countries) funded by the European Commission also launched a pilot survey on innovation in public services in several Northern European countries; much intelligence was generated about measurement and conceptual issues in public service innovation (Bugge et al., 2011). In 2010, the European Commission announced its intention to form a European Public Sector Innovation Scoreboard. To prepare for this, the Innobarometer 2010 was dedicated to innovation in the public sector. Its survey of over 4,000 public service organisations Europe-wide has confirmed the existence of significant innovation activity: 1) two-thirds of the public services surveyed introduced a new or significantly improved service during the three years covered by the survey; 2) the likelihood of innovation increases with the size of the institution; 3) the main driver of innovation is the introduction of new laws or regulations, followed by new policy priorities and E-government initiatives; and 4) the main mode of innovation is top-down rather than bottom-up (though we might suspect that this result is in part a function of the locations of interviewees in the organisations concerned) (European Commission, 2011).

\subsection{The Differentiation Perspective and Professional Rationalisation}

While the assimilation perspective is associated with the industrialisation of services (see Section 1.5), the differentiation perspective can be associated with another form of rationalisation geared toward innovation. This is what Gadrey (1996) describes as professional or cognitive rationalisation, as opposed to industrial rationalisation. This cognitive rationalisation, which is carried out, for example, in some consulting firms, can be divided into three strategies: typification of cases, formalisation of problem-solving procedures (methods), and the use of individual or organisational routines.

In public services too, we see this tension between industrial rationalisation and professional rationalisation. In professional rationalisation, the dominant principle is that the policy should set broad guidelines and not impose particular pathways or working methods. This must be left to the discretion of the public actors (at all levels: managers, but also basic agents), who should have more flexibility and freedom of interpretation and action at the local level. The differentiation perspective reflects a shift from the provision of a mass service (long dominant) to the provision of a more personalised service. 


\section{Inversion: The role of services in their customers' innovations}

The literature on innovation in services has recently introduced a new perspective to describe innovation in services (Gallouj, 2010). This perspective which Gallouj (2010) called the "inversion perspective" breaks with the idea of services dominated by manufacturing industry in terms of innovation, and goes further than just seeing service innovation as distinctive and demarcated from that of manufacturing industries. It sees service industries as potentially taking the lead in innovation processes, and shaping the innovation activities undertaken in other sectors. Indeed, services could tip the balance of power and be in a position where they dominate industry.

It should be noted that the inversion perspective introduces a break in our assimilationdifferentiation-integration analytical framework. It much more emphasises the change in the balance of power (the power rebalancing in terms of knowledge and innovation) between manufacturing and services than differences in terms of the nature of innovation. This is the reason why the inversion perspective is located in the middle of figure 1.

This inversion perspective describes the innovation activities of certain KIBS (especially research and development, engineering and consulting), which do not just innovate for themselves, but also play an extremely important role in their industrial and service clients' performance and innovation. This inversion can happen at the microeconomic level (the basic service transaction), but also at the macroeconomic level. There is thus, for EU countries, a positive correlation between the percentage of KIBS in total employment and performance in terms of innovation as measured by the Summary Innovation Index (European Commission, 2008). A different form of the dynamic may occur where service industries are important vehicles for the distribution of manufactured and other products. For instance, large retail firms are powerful enough to dictate to suppliers of food what ingredients should be used, to farmers what environmental standards should be pursued, and so on.

Knowledge-intensive business services (KIBS) are among the most innovative services, and they may also assist in their clients' innovation processes. They are information and knowledge processing machines to produce information and knowledge in the form of technological solutions, but also organisational, strategic, legal, fiscal and other solutions. They constitute an external source of knowledge and innovation for their customers (Miles et al. 1994; Djellal, 1995; Bessant and Rush, 1995; Muller and Zenker, 2001; Czarnitzki and Spielkamp, 2003; Toivonen, 2004; 2007; Wood, 2005; di Maria et al., 2012). This important development in the service economy has been described by den Hertog (2000; Bilderbeek and den Hertog, 1997) as constituting a new knowledge infrastructure that supplements and competes with the traditional infrastructure consisting mainly of public education and research institutions. It can also be interpreted as a new area of expression of the Schumpeterian concept of entrepreneurship. This is known as a Schumpeter Mark III model or consultant-assisted innovation model, or more generally as the interactional innovation model (Gallouj, 2002b), which would complement the well-known models of Schumpeter Mark I (the individual entrepreneur) and Schumpeter Mark II (endogenised entrepreneurship and innovation).

The actors in this Schumpeter Mark III model are not confined to private services. In some cases, public services may also fit this model to varying degrees. The role of public services in the innovation of other economic actors can be viewed from four perspectives: 
1) Public service policies supporting innovation in other economic activities. Public services that support economic activities, as well as public services in research and education, have always participated in this inversion perspective: for example, public research agencies may decide what lines of R\&D to fund, public technology transfer agencies may support uptake of particular standards and systems. Such policies are well known and widely documented. Suffice it to mention here a recent and important issue for public services policies supporting innovation in private services. The question is posed in terms of three of the analytical perspectives proposed for innovation in services, namely: assimilation, demarcation and integration (European Commission, 2003; RENESER, 2006; Rubalcaba, 2006). While many service innovation policies derive from an assimilationist perspective, and simply extend industrial policies (mainly scientific and technical) to services, there are examples of demarcation policies that take into account such specificities of services innovation such as difficulty in distinguishing the product from the process, a lesser role of $R \& D$ than in industry, less visible results because of the intangible nature of the service, potentially higher risks and stronger market failures, and a problem of ownership of the innovation developed in an interactive way through coproduction.

2) The second well-known role of public services as drivers of innovation in other activities is that of consumer and user of these innovations. This role can be seen as more or less active or passive. Public services, like any other businesses, need computers, transportation, and so on, which they buy from industrial suppliers, in which case they are "passive" consumers. This type of innovation falls within the assimilationist perspective mentioned earlier. But consumption and demand can also be used to guide technological trajectories. This is the case, for example, for public procurement. There is now considerable interest in using public procurement more generally to stimulate innovation (e.g. Aschhoff and Sofka, 2009) Edler and Georghiou, 2007; Stern et al, 2011) Thus, the Innobarometer 2010 survey (discussed in Section 2.3) indicates that over half of public service organisations consider that "procurement" contributed to innovative service solutions. This also applies to situations where public services act as "lead-users" (Dalpe et al., 1991).

3) Public services can also more or less passively provide information to private sectors. This is the case, for example, of public agencies specialising in the dissemination of scientific and technical information.

4) But public services may also play a more active role in the co-production of innovation. In this case, they are more firmly part of what we call the Schumpeter Mark III model or interactional innovation model. From this perspective, traditional innovation networks involving public services as co-producers are well known (Callon, 1991; Hakansson, 1989; Lundvall, 1992). But other, less well known networks have arisen or have been recognised more recently, namely Public-Private Innovation Networks in Services (see Section 2.4).

\section{Integration: the same innovation model for private and public goods and services}

The final perspective used to address the issue of innovation in services is integration or synthesis (Gallouj and Weinstein, 1997; Coombs and Miles, 2000). This perspective attempts to construct an analytical framework that encompasses the dynamics of innovation in all forms (technological and non-technological), and in both goods and services. The integration perspective can easily be extended to public services, especially as the boundaries between public services and market services are also becoming blurred, particularly as a result of 
deregulation policies. The integration perspective does not only concern the nature of innovation but also its modes of organisation. The last section illustrates how the shift from the linear to the open model of innovation involves both services (public and private) and manufacturing.

\subsection{Blurring of sectoral boundaries}

The literature shows some convergence between goods and services - so that we speak of the industrialisation and productisation of services and "servitisation" and tertiarisation of manufacturing. The "servitisation" or "servicisation" notion (Vandermerwe and Rada, 1998; Howells, 2001; Neely, 2008) typically, involves firms providing services related to the goods or raw materials that they produce (or sometimes services that are related to the production processes and information systems that they use). Some are "product services" such as aftersales support, some complement the good with services such as finance, insurance, maintenance, software, etc. (Furrer, 1997) A manufacturing firm may shift to a service focus, in which the firm sees its job in terms of providing the outcomes for customers that the good itself would be used to create: the firm may then sell a promised amount of service rather than selling - or even renting - the good. Manufacturers are becoming more service industry-like in other ways too, for example by adopting "post-Fordist" strategies of "mass customisation" and tailoring products more to customer specifications, by putting more emphasis on interaction and customer service. An increasing number of contemporary studies point to a blurring of boundaries between sectors and as to the nature of "products" (Barcet and Bonamy, 1999). Some research (Broussolle, 2001) shows that IT (as a technical system shared by industry and services) contributes to this "blurring."

The blurring of boundaries and the trend towards "all service" are manifested in different ways. For example, information and service play an increasing role in the value of most goods (industrial and agricultural). Sectors are "tertiarised" in that higher proportions of their workforce are engaged in service functions rather than directly producing goods. Whether potatoes, fragrance or calculators, service and information (R\&D expenditures, transportation, distribution, marketing, etc.) have become major components of the value produced. More generally, goods and services are decreasingly sold and consumed independently, but increasingly as solutions, systems, functions or experience. The blurring is also driven by the transformation of iconic industrial enterprises (e.g. IBM, Benetton) into service companies, to the extent that now most of their revenue comes from this type of activity. Another example of the blurring of boundaries is the new business model of certain industrial enterprises, which now lease their goods rather than selling them (Rank Xerox copiers) or refurbish or recycle goods rather than manufacturing them.

Along with this blurring of boundaries, a new message is appearing whereby certain businesses now no longer define themselves as goods manufacturers, but as providers of solutions, functions or experiences. New theoretical research prospects have emerged, including the functional economy (economics) (Stahel, 1997), the experience economy (economics) (Pine and Gilmore, 1999), the service-dominant logic ${ }^{5}$ (Vargo and Lusch, 2006), and characteristic-based approaches (Gallouj and Weinstein, 1997; Windrum and GarciaGoni, 2008; De Vries, 2006, Gallouj and Toivonen, 2011). We will focus in this paper only on the characteristics-based approach, which was specifically developed to address innovation. However it should be noticed that if the other approaches are not necessarily

\footnotetext{
${ }^{5}$ Although it focuses on service specificities, the S-D logic belongs to the integrative or synthesis perspective as far as it emphasises the service logic within both services and manufacturing activities.
} 
analytical models of innovation, they can easily be applied to address the innovation issue (new experiences, new functions, etc.).

\subsection{The characteristics-based approach: an integrative analytical framework for goods and services (including non-market services)}

To develop an integrative analytical framework for goods and services and their multiple forms of innovation, drawing on the work of Saviotti and Metcalfe (1984), Gallouj and Weinstein (1997) apply the Lancasterian model of goods to services. They define the product (whether it is a good or a service) as a set of vectors of characteristics: internal technical characteristics $[\mathrm{T}]$ and external technical characteristics $\left[\mathrm{T}^{\prime}\right]^{6}$, final or service characteristics $[\mathrm{Y}]$, internal competences $[\mathrm{C}]$ and external competences [ $\left.\mathrm{C}^{\prime}\right]$ (see. Figure 2).

Thus a service can be defined as the mobilisation of internal or external competences and internal or external techniques (tangible or intangible) to produce final or service characteristics (that is to say use values). Figure 2 can thus apply to several product configurations: a pure good (a car or a computer), an intangible product (an insurance contract, a financial product, a consulting service), a self-service outcome ([C']- $[\mathrm{T}]-[\mathrm{Y}])$, and hybrid solutions (goods and services): for example, a car and different types of associated services provided upstream or downstream (insurance, maintenance, financing, warranties, etc.).

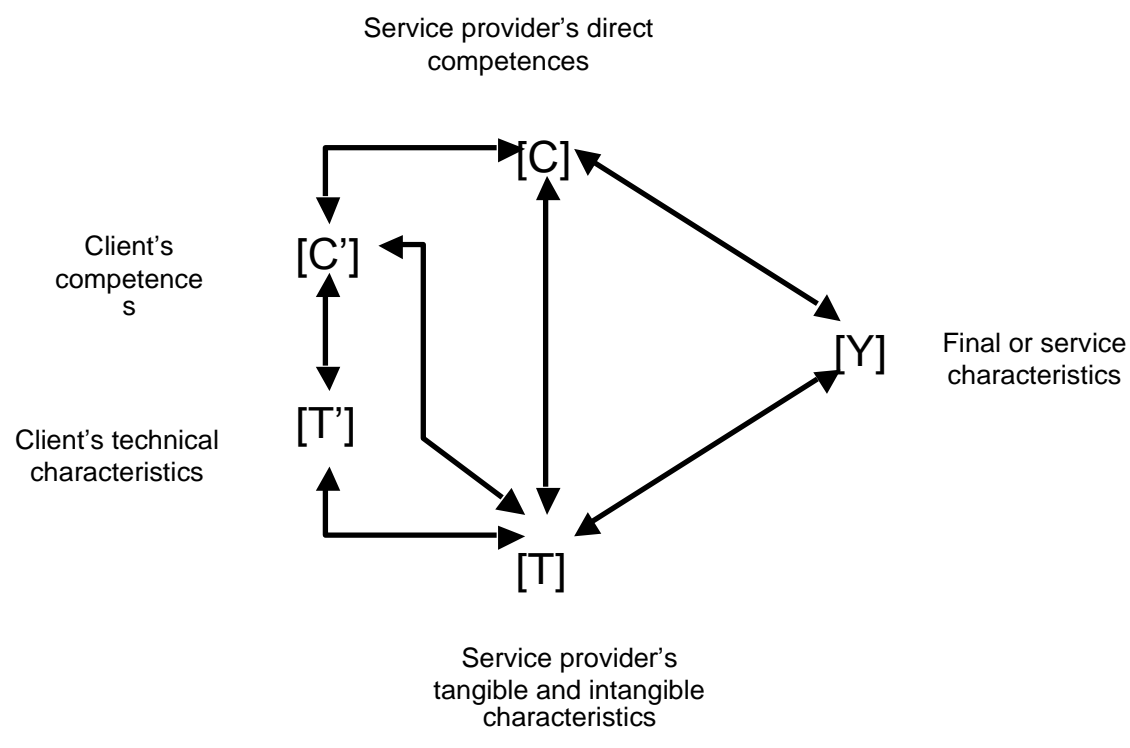

Figure 2: The product as the conjunction of vectors of characteristics and competences (after Gallouj and Weinstein, 1997)

In this representation, innovation reflects various changes to the characteristics: addition, subtraction, association, dissociation or formatting. These changes may be the result of natural learning processes or formalised $\mathrm{R} \& \mathrm{D}$, design and innovation activities. Different types of changes to the characteristics result in different models of innovation:

\footnotetext{
${ }^{6}$ The inclusion of clients' technical characteristics was suggested by De Vries (2006) in order to take into account the new channels of consumption and delivery (e.g. when consumers use their own technologies to access a service on the web).
} 
- Radical innovation - which describes the creation of a new set of characteristics $S=\left\{\left[C^{*}\right]\right.$, $\left.\left[\mathrm{C}^{*}\right],\left[\mathrm{T}^{*}\right],\left[\mathrm{T}^{*}\right],\left[\mathrm{Y}^{*}\right]\right\}$

- Improvement innovation, reflecting an increase in the prominence (or quality) of certain characteristics without changing the structure of the system of competences.

- Incremental innovation, which denotes the addition (and also possibly the elimination or replacement) of characteristics.

- Recombination innovation, based on the basic principles of dissociation and association of the final and technical characteristics.

- Formalisation innovation, based on the formatting and standardisation of characteristics.

This characteristics-based model of products and innovation has been amended several times (De Vries, 2006; Gallouj and Toivonen, 2011), in some cases with the explicit goal of (better) reflecting public services. Most notably, Windrum and Garcia-Goni (2008) suggest including the government in the model and developing a multi-agent model.

In a prior work (Gallouj, 2002a), we suggested associating a "conventionalist" approach to products with the Lancasterian characteristics-based model in order to take into account certain social and civic characteristics that are particularly important in public services (though these features can apply beyond these services). The conventionalist perspective (inspired by the work of Boltanski and Thévenot, 1991) suggests that products can be defined in terms of different sets of justificatory criteria based on:

- the industrial and technical world, whose outputs are described and estimated mainly in terms of volumes, flows and technical operations;

- the market and financial world, whose 'output' is envisaged in terms of value and monetary and financial transactions;

- the relational or domestic world, which values interpersonal relations, empathy and relationships of trust built up over time, and regards the quality of relationships as a key factor in estimation of the 'output';

- the civic world, which is characterised by social relations based on a concern for equal treatment, fairness and justice.

To integrate the diversity of these four worlds into our characteristics-based model, it is possible either to add characteristics from these different worlds to the different vectors, or to juxtapose several vectors of characteristics (service, technical characteristics) and competences referring to the different worlds mentioned (industrial, market, domestic and civic).

It may seem paradoxical to consider technical and process characteristics according to different worlds, since it might be thought that these characteristics are all technical. However, techniques are not neutral; as p producers of service characteristics, they are valueladen, reflecting human choices. Some technical solutions may be deemed to be fairer or more equitable than others (e.g. techniques adapted for the disabled). With regard to intangible technical characteristics (methods, organisation modes), one can easily imagine that certain organisational arrangements may fall within the domestic and civic worlds (arrangements to ensure anonymity, confidentiality, discretion, fairness in the order in which requests are processed).

The same is true for competences. The vector of competences must take into account what could be called social and civic competences, that is to say, the ability to provide a service or simply to maintain a relationship with customers - recalling that public services often deal 
with people in severely difficult socio-economic situations. Such social and civic competences can be accepted or promoted by the organisation or they can be repressed. The competences of certain customers [C'k] may be particularly weak (socioeconomically disadvantaged customers, cultural and cognitive disabilities). This weakness can or should be compensated by the social and civic competences of empathy and "translation" on the part of front-office agents.

This analytical framework for products and innovation has been applied in a number of public services: The French Post office (postal and financial services), the French family welfare offices (CAF) and the French public employment service (ANPE). In this extended representation, innovation is also envisaged in terms of various changes in the characteristics.

\subsection{From the linear model to the open model}

Innovation can come about in more or less spontaneous (unpredictable) or planned (relatively predictable) ways. It is planned and predictable when it takes place within clearly identified structures (e.g. R\&D departments, project groups) and in accordance with previously established processes. Planned innovation programs of this type are of course implemented by some service organisations (Sundbo and Gallouj, 1999; Tidd and Hull, 2010). Thus in management sciences there is a fertile theoretical tradition advocating the application to services of new product development (NPD) methodologies, whereby new services are designed in accordance with planned, systematic processes labelled as New Service Development (NSD) (Scheuing and Johnson, 1989; De Brentani, 1991). It is noteworthy that the NSD literature is only loosely connected with studies deriving from the service innovation field; it also stresses the ways in which features like intangibility and coproduction are important to service development.

The literature on innovation in services has emphasised the role of interactive structures and processes in relation to the general perspective of open innovation (Chesbrough, 2003, 2011), however. However these structures are not specific to services as far as they are also implemented inside manufacturing firms. In other words the integration perspective not only involves the nature of innovation but also its modes of organisation. The general perspective of open innovation includes the chain-linked or interactive model advanced by Kline and Rosenberg, which we have already mentioned, but also encompasses different cooperative models that are more or less sophisticated and formalised. This includes unplanned or emerging models such as the rapid application model, the practice-based model, "bricolage" innovation and ad hoc innovation. The rapid application model is a model in which planning does not precede production, as it does in the traditional linear model. Once the idea emerges, it is immediately developed as the service in question is being provided. Thus, the process of providing the service and the process of innovation are here one and the same (Toivonen, 2010). The practice-based model involves identifying changes in service practices and developing and institutionalising them. The bricolage model describes change and innovation as the consequences of unplanned activities carried out in response to random events and characterised by trial and error and 'learning on the job' (Sanger and Levin, 1992; Fuglsang, 2010; Styhre, 2009). Ad hoc innovation (Gallouj and Weinstein, 1997) can be defined as the process of constructing a (novel) solution to a problem identified by the client company - an interactive process, which requires the participation of the customer and which is consubstantial with the process of service provision. It can only be separated from service 
provision in retrospect, and the innovation is liable to be recognised as such only after the fact.

Research on how innovation is organised in public services is rare (except for research on the role of public research services, including those within hospitals) ${ }^{7}$. For many public services, it seems that change and innovation are mainly top-down, planned and formalised processes, as indicated by the Innobarometer 2010 survey discussed in section 2.3. Despite this formalised character, to our knowledge, the literature makes no mention of any practical applications of the linear NSD perspective to this type of public services.

However, various studies have stressed the existence and importance of what we have called invisible innovation, and NESTA labels "hidden innovation" - for some of their work on public services see NESTA (2007). Various modes of organisation and forms of innovation tend to be overlooked by those approaching innovation in more formal terms (Fuglsang, 2008, 2010). These tend to be "bottom-up" modes, including the unplanned and informal models mentioned above (ad hoc model, practice-based model, bricolage model, rapid application model, etc.). It is likely that much innovation occurs at local levels in public service organisations, and one problem may well be that much of this is not widely known and diffused in the organisations.

It should be noted that a recent literature in the field of political science is focused on the rise of what is labelled "collaborative innovation in the public sector" (Sørensen and Torfing, 2012). This multi-actor collaboration is envisaged as taking place inside public administrations, between members of different public bodies, but also with private partners.

Additionally, and highly related to the open innovation concept, new innovation networks, labelled Public Private Innovation Networks in Services (PPINS) ${ }^{8}$ are developing. PPINS involve collaborations between public, private and third-sector service organisations in the field of innovation (Gallouj, Rubalcaba and Windrum, 2013). The approach to PPINS differs from that applied to traditional innovation networks in several ways. Firstly, the relationships between public and non-market actors and private actors lie at the heart of the analysis. Secondly, we see service providers as the main actors in them. Finally (and this is the corollary of the preceding characteristic), non-technological innovation (service innovation), which is often overlooked in the literature, is taken into account, and is often a central feature of the partnership.

\section{Conclusion}

Although the association of the terms "service" and "innovation" may long have seemed incongruous (service had the negative connotations of servitude and public services), this is no longer the case today. This paper aimed to examine the issue of innovation in public services in light of the literature on innovation in services. The processes for generating creative ideas, and for selecting among them to develop some into applicable innovations, are

\footnotetext{
7 There is, however, considerable practical advice about innovation provided in various public service organisations in various countries. In the UK health service alone, we can point to such resources as http://www.innovations.nhs.uk/, $\quad$ http://www.dh.gov.uk/health/category/policy-areas/nhs/innovation/, and http://www.institute.nhs.uk/ (accessed 19/12/2013).

${ }^{8}$ These innovation networks were studied under the European project ServPPIN (The Contribution of Public and Private Services to European Growth and Welfare, and the Role of Public-Private Innovation Networks, FP7). See http://www.servppin.com/ (accessed 19/12/2013).
} 
many and varied in public services, just as they are across service industries more generally. Many of the general features of innovation processes noted in innovation studies more generally may be expected to apply to the dynamics of public service innovation, as we have seen. The specific points raised in studies of innovation in large systems and of service innovation are liable to be particularly relevant ones. It is remarkable that the public services have been neglected for so long by the bulk of innovation scholars. Taking them into account will extend our understanding of the diversity of innovation processes - not least across different public services and even across organisations within the same nominal bloc of services) - and of the institutional settings that shape them.

In recent years the service innovation literature has developed different theoretical perspectives, which we have interpreted in terms of assimilation, demarcation, inversion and synthesis (ADIS). The ADIS analytical framework is a heuristic that can be applied without too much difficulty to public services; it throws light upon issues of public service innovation, but may require some additional reflection.

Thus in the case of the assimilationist perspective, for example, it is important to consider a certain dualism in the public sector. We must distinguish between at least two different groups: first, the science-based public services (public research laboratories, universities, certain aspects of hospital services) and, secondly, less science-based activities. The first group is at the heart of today's scientific and technical innovation dynamic. It consists of activities that actively and autonomously produce scientific and technical innovations. The idea of assimilation seems inappropriate in this case; this type of innovation has much in common with innovation in (high-tech) industry and, indeed, a mainly technological focus may be largely justified. The dynamics of innovation in the second group, the other public service sectors (e.g., governments), in contrast, fit better into the traditional assimilationist perspective as manifested in the less innovative market services. This is a perspective centred on technological innovation that is adopted rather than produced, instead of other more specific, non-technological forms of innovation.

The inversion perspective also requires a nuanced interpretation. It is obvious that public services influence innovation in other sectors in different ways: indeed, they can fit into an interactional innovation model (Schumpeter Mark III). This is true not only for science-based public services (public laboratories, etc.), but also for government agencies that support innovation or governments that use public procurement to guide innovation trajectories. However, the idea of inversion can be a misnomer. It presupposes a "normal" (non-inverted) situation in the past, which is not the case for the examples cited. For instance, public policies supporting innovation have always existed.

The issue of innovation in public services has also been discussed recently from the perspectives of demarcation and synthesis. Some recent studies look at the specificities of innovation in public services from both a qualitative and quantitative standpoint. These specificities (whether they concern the nature of the innovation or the organisational methods) are considered from a "double differentiation" perspective: differentiation with respect to manufacturing and differentiation with respect to market services. But demarcation need not be the end of the story: public services should also fit into the integrative theoretical models. We propose that characteristics-based approaches can provide interesting avenues of research for that purpose. 


\section{Bibliography}

Abernathy W., Utterback J. (1978), Patterns of industrial innovation, Technology Review, vol. 80, pp. 41-47.

APEC/ Ministry of Public Administration and Security (2005) Government Innovation, Korea's Energy for Hope Seoul: Republic of Korea Ministry of Public Administration and Security, http://www.mopas.go.kr/gpms/view/jsp/download/userBulletinDownload.jsp?userBtBean. bbsSeq $=1002948$ \&userBtBean.ctxCd=1032\&userBtBean.orderNo=78259 (accessed 1912-2012).

Arduini D., Belotti, F., Denni, M., Giungato, G., and Zanfei, A. (2010), Technology adoption and innovation in public services the case of e-government in Italy, Information Economics and Policy, vol. 22, pp. 257-275

Aschhoff B., Sofka W. (2009), Innovation on demand: can public procurement drive market success of innovation? Research Policy, vol. 38, pp. 1235-1247.

Attour A., Longhi C. (2009), Fracture numérique, le chaînon manquant: les services d'eadministration locale dans les communes françaises, Les Cahiers du numérique, 2009/1, Vol. 5, pp. 119-146.

Autor, D. H., Levy, F. and Murnane, R, J. (2003), The Skill Content of Recent Technological Change: An Empirical Exploration, Quarterly Journal of Economics, vol 118 (4), pp. 1279-333.

Bacache-Beauvallet M., Bounie D., François A. (2011), Existe-t-il une fracture numérique dans l'usage de l'administration en ligne? Revue économique, 2011/2, Vol. 62, pp. 215235.

Barcet A., Bonamy J. (1999), Eléments pour une théorie de l'intégration biens/services, Économies et Sociétés, série EGS, n²1, 5, pp. 197-220.

Barras R. (1986), Towards a Theory of Innovation in Services, Research Policy, 15, pp. 161173.

Barras R. (1990), Interactive Innovation in Financial and Business Services: The Vanguard of the Service Revolution, Research Policy, 19, pp. 215-237.

Becheikh N., Halilem N., Jbilou J., Landry R. (2009), Vers une conceptualisation de l'innovation dans le secteur public, Economies et Sociétés, série EGS, n¹0, 4/2009, pp. $579-614$.

Bekkers V., van Duivenboden H., and M. Thaens (2006), Public Innovation and Communication technology: relevant backgrounds and concepts, in Bekkers V. van Duivenboden H. and Thaens M. (eds), Information and Communication Technology and Public Innovation, IOS Press, Amsterdam/Berlin/Oxford/Tokyo/Washington DC, pp. 321.

Benington, J., and M. H. Moore (2011), Public value: theory and practice, New York: Palgrave Macmillan.

Bessant J., Rush H., (1995), Building bridges for innovation: the role of consultants in technology transfer, Research Policy, 24, pp. 97-114.

Bilderbeek R., Den Hertog P., (1997), The new knowledge infrastructure, SI4S project, European Commission, TSER programme.

Boltanski, L. Thévenot, L. (1991), De la justification. Les économies de la grandeur, Gallimard, Paris.

Borins, S. (2001), "Public management innovation - Toward a global perspective", American Review of Public Administration, 31(1), pp. 5-21. 
Broussolle D. (2001), Les NTIC et l'innovation dans la production de biens et services: des frontières qui se déplacent, 11th RESER international conference, Groupe ESC-Grenoble, October.

Bugge M., Mortensen P., Bloch C. (2011), Measuring Public Innovation in Nordic Countries, NIFU, Norway.

Callon M. (1991), "Réseaux technico-économiques et irréversibilité", in Boyer et al. (eds), Figures de l'irréversibilité en économie, Paris, Edition de l'EHESS, pp. 195-230.

Chesbrough H., (2003) Open Innovation: The New Imperative for Creating and Profiting from Technology, Boston: Harvard Business School Press.

Chesbrough H., (2011) Open Services Innovation: Rethinking Your Business to Grow and Compete in a New Era, Boston: Harvard Business School Press.

Clark J., Good B., Simmonds P. (2008), Innovation Index Working Paper, Innovation in the Public and Third Sectors, September, Nesta.

Coombs R. and Miles I. (2000), Innovation measurement and services: the new problematique, in Metcalfe S. and Miles I. (eds) Innovation systems in the service economy. Measurement and case study analysis, Kluwer, Boston, pp. 85-103.

Czarnitzki, D., Spielkamp A. (2003), Business services in Germany: Bridges for innovation, The Service Industries Journal, 23 (2), pp.1-30.

Dalpé R., DeBresson C., Xiaoping H. (1992), The public sector as first user of innovations, Research Policy, 21, pp. 251-263.

Davies, A. (2004), Moving base into high-value integrated solutions: a value stream approach", Industrial and Corporate Change, 13(5), pp. 727-756.

De Brentani U. (1991), Success factors in developing new business services, European Journal of marketing, 25(2), pp. 33-59.

De Vries, E. (2006), Innovation in services in networks of organisations and in the distribution of services, Research Policy, Volume 35, Issue 7, pp. 1037-1051.

den Hertog, P. (2000) "Knowledge-Intensive Business Services as Co-Producers of Innovation" International Journal of Innovation Management Vol. 4, No. 4 pp. 491-528.

di Maria, E., Grandinetti, R., and Di Bernardo, B. (eds) (2012), Exploring KnowledgeIntensive Business Services - Knowledge Management Strategies, London, Palgrave.

Dixit A. (2002), Incentives and organisations in the public sector: an interpretative review, Journal of Human Resources, 23(4), pp. 696-727.

Djellal F., (1995), Changement technique et conseil en technologie de l'information, L'Harmattan, Paris.

Djellal F., Francoz D., Gallouj C., Gallouj F., Jacquin Y. (2003), Revising the definition of research and development in the light of the specificities of services, Science and Public Policy, 30/6, pp. 415-430.

Djellal F., Gallouj F. (2005), Mapping innovation dynamics in hospitals, Research Policy, Vol. 34, pp. 817-835.

Djellal F., Gallouj F. (2007), Innovation in hospitals: a survey of the literature, The European Journal of Health Economics, Vol. 8, n³, pp. 181-193.

Djellal F., Gallouj F. (2008), A model for analysing the innovation dynamic in services: the case of architectural-type services, International Journal of Services Technology and Management, 9 (3/4), 285-304.

Droege H., Hildebrand D., Heras Forcada M. (2009), Innovation in services: present findings, and future pathways, Journal of Service Management, vol. 20 (2), pp. 131-155.

Earl, L. (2004) An historical comparison of technological change, 1998-2000 and 2000-2002, in the private and public sectors Ottawa: Statistics Canada (Science, Innovation and Electronic Information Division) Cat. No. 88F0006XIE200407

Edler J., Georghiou L. (2007), Public procurement and innovation: resurrecting the demand 
side, Research Policy, 36, 949-963.

European Commission (2003), The competitiveness of business-related services and their contribution to the performance of European enterprises, Communication from the Commission to the Council and the European Parliament, COM (2003):747, EU, Brussels.

European Commission (2008), European innovation scoreboard.

European Commission (2011), Flash Eurobarometer n³05, 2010 Innobarometer.

Evangelista R. (2000). Sectoral patterns of technological change in services, Economics of innovation and new technology, 9, pp. 183-221.

Evangelista R., Savona M. (2003), Innovation, employment and skills in services: firm and sectoral evidence, Structural Change and Economic Dynamics, 14, pp. 449-474.

Fox, K.J. (1999), "Efficiency at different levels of aggregation: public vs. private sector firms", Economic Letters, 65 (2), pp. 17-176.

Fuglsang L. (2008), Capturing the benefits of open innovation in public innovation: a case study, International Journal of Services Technology and Management, Vol. 9, n³-4, p. 234-248.

Fuglsang L. (2010), Bricolage and invisible innovation in public service innovation, Journal of Innovation Economics, 2010/1, n5, pp. 67-87.

Furrer O. (1997), "Le rôle stratégique des "services autour des produits"", Revue française de gestion, mars-avril-mai, pp. 98-107.

Gadrey J. and Gallouj F. (1998), The provider-customer interface in business and professional services, The Service Industries Journal, Vol. 18, n², April, pp. 1-15.

Gadrey J., (1992), Socio-économie des services, La Découverte, Paris ; 3rd edition, 2003.

Gadrey, J., (1996) Services: la productivité en question, Desclée de Brouwer.

Gallouj F. (1998), Innovating in reverse: services and the reverse product cycle, European Journal of Innovation Management, Vol. 1, n³, 123-138.

Gallouj F. (2002a), Innovation in the service economy: the new wealth of nations, Edward Elgar, Cheltenham, Northampton.

Gallouj F. (2002b), Interactional innovation: a neoschumpeterian model, in Sundbo J. and Fuglsang L. (eds.), Innovation as strategic reflexivity, Routledge, London, New York, pp. 29-56.

Gallouj F. (2010), Services innovation: assimilation, differentiation, inversion and integration, chapter 75, in Bidgoli H. (ed), The Handbook of Technology Management, John Wiley and Sons, pp. 989-1000.

Gallouj F., Djellal F. (eds) (2010), The Handbook of Innovation and Services: a multidisciplinary perspective, Edward Elgar Publishers.

Gallouj F., Rubalcaba L. Windrum P. (2013), Public Private Innovation Networks in Services, Edward Elgar (forthcoming).

Gallouj F., Toivonen M. (2011), Elaborating the characteristics-based approach to service innovation: making the service process visible, Journal of Innovation Economics, 2011/2, $\mathrm{n}^{\circ} 8$, p. 33-58.

Gallouj F., Weinstein O. (1997), Innovation in services, Research Policy, 26 (4-5), pp. 537556.

Gault F. (2012), User innovation and the market, Science and Public Policy, 39(2012), pp. $118-128$

Glushko, R.J. and Tabas, L. (2009), Designing service systems by bridging the "front stage" and "back stage", Information Systems and E-Business Management, vol. 7 no. 4 pp. 407 427.

Greenhalgh, T., Robert, G., MacFarlane, F., Bate, P., and Kyriakidou O. (2005), Diffusion of innovations in health service organisations: A systematic literature review. London: Blackwell Publishers 
Hakansson H. (1989), Corporate technological behaviour, cooperation and networks, London, Routledge.

Halvorsen T., Hauknes J., Miles I., R. Rannveig (2005), On the differences between public and private sector innovation, PUBLIN report D9.

Hartley J. (2005), Innovation in governance and public services: Past and present, Public Money and Management, 25 (1), January, 27-34.

Hill pp. (1977), On goods and services, Review of Income and Wealth, Vol. 23, n4, December pp. 315-338.

Hipp C., Grupp H. (2005), Innovation in the service sector: The demand for service-specific innovation measurement concepts and typologies, Research Policy, 34, 4, 517-535.

Hollander SC (1966), Notes on the retail accordion. Journal of Retailing, Vol. 42, n², pp. 2434.

Howells, J. (2001). "The Nature of Innovation in Services." In OECD, Innovation and Productivity in Services, OECD Proceedings Industry, Services and Trade. Paris: Organisation for Economic Co-operation and Development (OECD).

Hughes A., Moore K., Kataria N. (2011), Innovation in Public Sector Organisations: A pilot survey for measuring innovation across the public sector, London: NESTA.

Jiao, J., Ma, Q., Tseng, M.M. (2003), Towards High Value-added Products and Services: Mass Customisation and Beyond, Technovation, vol. 23 no. 10 pp. 809-821.

Knox Lovell C.A. (2002), "Performance assessment in the public sector", in Fox, K. (ed.), Efficiency in the public sector, Dordrecht, Kluwer Academic Publishers, pp. 11-35.

Koch P., Cunningham P., Schwabsky N., Hauknes J. (2005), Innovation in the Public sector. Summary and policy recommendations. Oslo: Publin Report n ${ }^{\circ}$ D24.

Lekhi, R. (2007), Public Service Innovation, (Report from Research Republic LLP), London: The Work Foundation.

Levitt, T. (1976), The Industrialisation of Service, Harvard Business Review vol. 54 no. 5 pp63-74.

Lindsay C.M., (1976) “A theory of government enterprise”, Journal of political economy, 84(5), pp. 1061-1077.

Lundvall B.-A. (ed) (1992) National systems of Innovation, London: Pinter Publishers.

McNair MP (1958), Significant trends and developments in the post war period. In: AB Smith (ed) Competitive distribution in a free high level economy and its implication for the university, University of Pittsburgh Press, Philadelphia, PA.

Miles I. (1993), Services in the New Industrial Economy, Futures vol. 25 no 6 pp. 653-672.

Miles I. (1998), Services, Systems and Innovation - Cinderella comes to the ball, Services and Systems Worksop, CRIC, Manchester, March.

Miles I. (2012), "Public Service Innovation: What messages from the collision of Innovation Studies and Services Research", in Osborne S.P. and Brown L. (eds) Handbook of Innovation and Change in Public Sector Services (forthcoming).

Miles I. et al., (1994), Knowledge-Intensive Business Services: Their Role as Users, Carriers and Sources of Innovation, Manchester: PREST, Manchester University.

Miles, I, (2005) "Be Here Now" INFO Vol. 7 No. 2, 2005, pp. 49-71

Miles, I, (2007), "R\&D beyond Manufacturing: the strange case of services' R\&D" $R \& D$ Management, vol. 37, no 3 pp. 249-268

Miles, I, (2008) "Patterns of innovation in service industries", IBM Systems Journal, Vol 47 No 1 pp115-128

Miles, I. (2010), "Service Innovation" in Maglio, P., Kieliszewski, C.A., and Spohrer, J.C. (eds) The Handbook of Service Science, pp. 511-534, New York: Springer 2010

Moore, M. H. (1995), Creating public value: strategic management in government, Cambridge, Mass.: Harvard University Press. 
Mulgan G., Albury D. (2003) Innovation in the Public Sector, London: Strategy Unit, Cabinet Office UK.

Muller E. and Zenker A. (2001), Business services as actors of knowledge transformation: The role of KIBS in regional and national innovation systems, Research Policy, 30 (9), pp. 1501-1516.

Neely, A. (2008) "Exploring the financial consequences of the servitisation of manufacturing", Operations Management Research, vol. 1 no.2, pp. 103-118.

NESTA (2007) Hidden Innovation London: National Endowment for Science, Technology and the Arts, available at http://www.nesta.org.uk/publications/reports/assets/features/hidden innovation accessed $19 / 12 / 2013$

Newmark, A. J. (2002), An Integrated Approach to Policy Transfer and Diffusion, Review of Policy Research vol. 19, no. 2, pp. 151-178.

OECD (1993), Usage Indicators - a new foundation for Information Technology policies, Paris: OECD, Information Computer Communications Policy ICCP 31.

OECD (1992), Oslo Manual: Guidelines for collecting and interpreting innovation data, $1^{\text {st }}$ Edition, Paris, OECD.

OECD (2005), Oslo Manual: Guidelines for collecting and interpreting innovation data, $3^{\text {rd }}$ Edition, Paris, OECD,

OECD (2011), Public Research Institutions: Mapping Sector Trends, Paris.

Pavitt, K. (1984). 'Sectoral Patterns of Technical Change: Towards a Taxonomy and a Theory, Research Policy vol.13, pp.343-374.

Osborne, S. P. (ed.) (2010), The new public governance? Emerging perspectives on the theory and practise of public governance, London: Routledge.

Pine, J., Gilmore, J. (1999), The Experience Economy, Harvard Business School Press, Boston.

Platts, J., \& Williamson, Y. (2000). "The use of cognitive-behavioural therapy for counselling in schools" in Barwick, N. (ed.), Clinical Counselling in Schools, pp. 96-107, London: Routledge.

Potts J. (2009), The innovation deficit in public services: The curious problem of too much efficiency and not enough waste and failure.

Rees R. (1984), Public enterprise economics, $2^{\text {nd }}$ éd., London, Weidenfeld and Nicholson.

RENESER (2006) Research and Development Needs of Business Related Service Firms (RENESER Project), Delft: Dialogic innovatie \& interactie, Available at: http://pub419.bi.fraunhofer.de/fhg/Images/2004046RENESERreport tcm419-135765.pdf (accessed 19/12/2013)

Roach, S.S. (1987), America's Technology Dilemma: a Profile of the Information Economy, Morgan Stanley, Special Economic Studies, New York.

Rosenberg N. Nelson R. (1994), American Universities and technical advance in industry, Research Policy, 23(3), pp. 323-348.

Rubalcaba L. (2006), Which policy for innovation in services? Science and Public Policy, Vol. 33, n¹0, pp. 745-756.

Salter, A. and Tether, B. (2006) 'Innovation in Services: Through the Looking Glass of Innovation Studies', Background paper for the Advanced Institute of Management (AIM) Research's Grand Challenge on Service Science. (http://aimresearch.org)

Sanger M. B., Levin M. A. (1992), Using Old Stuff in New Ways: Innovation as a Case of Evolutionary Tinkering, Journal of Policy Analysis and Management, 11(1), pp. 88-115.

Saviotti P.P., Metcalfe J.S. (1984), A theoretical approach to the construction of technological output indicators, Research Policy, 13, pp. 141-151. 
Scheuing E.E, Johnson E.M. (1989), A proposed model for new service development, Journal of service marketing, 3(2), pp. 25-35.

Scott-Kemmis D. (2009), Assessing Policies, Programs and Other Initiatives to Promote Innovation in the Public Sector: International Case Studies, Management Advisory Committee Report 9 - ANNEX 1, November 2009.

Seddon, J. (2008). Systems Thinking in the Public Sector: The Failure of the Reform Regime and a Manifesto for a Better Way. Triarchy Press: Axminster.

Smith, A. (1776), An Inquiry into the Nature and Causes of the Wealth of Nations.

Soete, L. and M. Miozzo (1990), Trade and Development in Services: a Technological Perspective. Maastricht Economic Research Institute on Innovation and Technology (MERIT) Working paper 89-031.

Sørensen, E., and J. Torfing (2012) "Introduction: Collaborative innovation in the public sector." The Innovation Journal; The Public Sector Innovation Journal, 17, pp. 1-14

Stahel, W. (1997). The Functional Economy: Cultural and Organisational Change, in Richards D.J. (ed) The industrial green game: implications for environmental design and management. Washington DC, National Academy Press, pp. 91-100.

Stern, P., Hellman, J., Rijnders-Nagle, M., Terrell, M. \& Åström, T. (2011) How Public Procurement can stimulate Innovative Services Technopolis, Report to Nordic Innovation Centre available at http://www.technopolisgroup.com/resources/downloads/n1/2011_Report_Public_Procurement_NICE.pdf (accessed 19/12/2013).

Styhre A. (2009), Tinkering with material resources: Operating under ambiguous conditions in rock construction work. The Learning Organisation 16 (5), pp. 386-397.

Suire R. (2007), Encastrement social et usages de l'Internet: une analyse jointe du commerce et de l'administration électronique, Economie et Prévision, 2007/4, n¹80-181, pp. 161174.

Sundbo J. and Fuglsang L. (eds.) (2002), Innovation as strategic reflexivity, Routledge, London, New York.

Sundbo J., Gallouj F. (1999), Innovation as a loosely coupled system in services, International Journal of Services Technology and Management, Vol. 1, $\mathrm{n}^{\circ} 1$, pp. 15-36.

Sundbo, J. (2002). "The service economy: standardisation or customisation?" Service Industries Journal, 22(4), 93-116.

Tidd J., Hull F. (2010), Service innovation: development, delivery and performance, in Gallouj F. Djellal F. (eds), The handbook of innovation and services, Edward Elgar, pp. 250-278.

Toivonen M. (2004), Expertise as business: Long-term development and future prospects of knowledge-intensive business services, $\mathrm{PhD}$, Helsinki University of Technology.

Toivonen M. (2007). Innovation policy in services: The development of knowledge-intensive business services (KIBS) in Finland. Innovation: Management, Policy \& Practice, Vol. 9 , No. 3-4, pp. 249-261.

Toivonen M. (2010), Different types of innovation processes in services and their organisational implications, in Gallouj F. Djellal F. (eds), The handbook of innovation and services, Edward Elgar, pp. 221-249.

Valminen, K. (2011) "Towards customer-oriented productisation in services" in Sundbo, J. And Toivonen, M. (eds) User-Based Innovation in Services, Cheltenham: Edward Elgar.

Valminen, K., and Toivonen, M. (2011). "Seeking efficiency through productisation: a case study of small KIBS participating in a productisation project." The Service Industries Journal, vol 32 no.2 pp. 273-289.

Vandermerwe, S., Rada J. (1988). "Servitisation of Business: Adding Value by Adding Services.” European Management Journal 6(4), pp. 314-324. 
Vargo, S. L., Lusch R. (2006) "Service-Dominant Logic: What it is, What it is not, What it might be" in Lusch R. and Vargo, S.L. (eds.), The Service-Dominant Logic of Marketing: Dialog, Debate, and Directions, Armonk, M.E. Sharpe, pp. 43-56.

Windrum P. and Koch P. (eds), 2008, Innovation in public sector services. Entrepreneurship, Creativity and Management, Cheltenham and Northampton, MA: Edward Elgar.

Windrum P., Garcia-Goni M. (2008) A neo-Schumpeterian model of health services innovation, Research Policy, 37, pp. 649-672.

Winspear, D. and Robertson, C. (2005), "The use of cognitive behavioural therapy within Jobcentre Plus: helping customers with disabilities and health problems back into work." Journal of Occupational Psychology, Employment and Disability, vol.7 no.1 pp. 73-82

Wood P. (2005), A service-informed approach to regional innovation - or adaptation? The Service Industries Journal, 25 (4), pp. 429-445. 